\title{
Physical and chemical consequences of artificially deepened thermocline in a small humic lake - a paired whole-lake climate change experiment
}

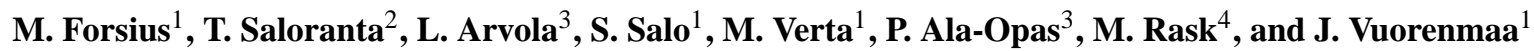 \\ ${ }^{1}$ Finnish Environment Institute (SYKE), P.O. Box 140, 00251 Helsinki, Finland \\ ${ }^{2}$ Norwegian Institute for Water Research (NIVA), Gaustadalléen 21, 04349 Oslo, Norway \\ ${ }^{3}$ University of Helsinki, Lammi Biological Station, Pääjärventie 320, 16900 Lammi, Finland \\ ${ }^{4}$ Finnish Game and Fisheries Research Institute, Evo Fisheries Research Station, 16970 Evo, Finland
}

Received: 8 April 2010 - Published in Hydrol. Earth Syst. Sci. Discuss.: 11 May 2010

Revised: 22 November 2010 - Accepted: 9 December 2010 - Published: 21 December 2010

\begin{abstract}
Climate change with higher air temperatures and changes in cloud cover, radiation and wind speed alters the heat balance and stratification patterns of lakes. A paired whole-lake thermocline manipulation experiment of a small $\left(0.047 \mathrm{~km}^{2}\right)$ shallow dystrophic lake (Halsjärvi) was carried out in southern Finland. A thermodynamic model (MyLake) was used for both predicting the impacts of climate change scenarios and for determining the manipulation target of the experiment. The model simulations assuming several climate change scenarios indicated large increases in the whole-lake monthly mean temperature $\left(+1.4-4.4^{\circ} \mathrm{C}\right.$ in April-October for the A2 scenario), and shortening of the length of the ice covered period by $56-89$ days. The thermocline manipulation resulted in large changes in the thermodynamic properties of the lake, and those were rather well consistent with the simulated future increases in the heat content during the summer-autumn season. The manipulation also resulted in changes in the oxygen stratification, and the expansion of the oxic water layer increased the spatial extent of the sediment surface oxic-anoxic interfaces. In addition, the experiment affected several other chemical constituents; concentrations of organic carbon, TotN, and $\mathrm{NH}_{4}$ showed a statistically significant decrease, likely due to both changes in hydrological conditions during the experiment period and increased decomposition and sedimentation. In comparison with the results of a similar whole-lake manipulation experiment in a deep, oligotrophic, clear-watered lake in Norway, it is ev-
\end{abstract}

Correspondence to: M. Forsius (martin.forsius@ymparisto.fi) ident that shallow dystrophic lakes, common in the boreal region, are more sensitive to physical perturbations. This means that projected climate change may modify their physical and chemical conditions in the future.

\section{Introduction}

The thermal regime and stratification of lakes is one of the key factors in lake ecosystems determining ecosystem structure and function at all trophic levels (e.g. Schindler et al., 1996a; Xenopoulus and Schindler, 2001). Main components include the efficiency of nutrient recycling (Fee et al., 1992, 1996), amount of photosynthetically active radiation in the mixed layer (Jones and Arvola, 1984; Fee et al., 1992), the vertical distribution of organisms (Arvola et al., 1992; Peeters et al., 2007), and the habitat volume available to cold stenotherms (Schindler et al., 1996a). In addition to direct physical forcing, the thermal stratification of lakes is controlled by complex interactions of several environmental factors such as wind fetch and lake size, basin morphometry, altitude, and water clarity/dissolved organic carbon (DOC) (e.g. Fee et al., 1996; Snucins and Gunn, 2000; Livingstone et al., 2005; Saloranta et al., 2009).

Long term changes in weather patterns (temperature, precipitation, wind speed, solar radiation, etc.) have both direct impact on the lake thermodynamic properties and light climate, and indirect impact on chemical and biological conditions via the lake catchment (Forsius et al., 1997; Järvinen et al., 2002; Nickus et al., 2010). In colder regions where lake ice and snow cover is formed, lakes may show a particularly

Published by Copernicus Publications on behalf of the European Geosciences Union. 
Table 1. Morphologic and hydrographic characteristics of lakes Halsjärvi (experimental lake) and Valkea-Kotinen (reference lake).

\begin{tabular}{lll}
\hline & $\begin{array}{l}\text { Halsjärvi } \\
\text { (experimental) }\end{array}$ & $\begin{array}{l}\text { Valkea-Kotinen } \\
\text { (reference) }\end{array}$ \\
\hline Latitude (WGS 84) & $61^{\circ} 13,56^{\prime}$ & $61^{\circ} 14,54^{\prime}$ \\
Longitude & $25^{\circ} 08,38^{\prime}$ & $25^{\circ} 03,76^{\prime}$ \\
Elevation (m) & 131 & 156 \\
Lake area $\left(\mathrm{km}^{2}\right)$ & 0.047 & 0.041 \\
Lake maximum depth $(\mathrm{m})$ & 5.9 & 6.4 \\
Lake volume $\left(\mathrm{m}^{3}\right)$ & 130000 & 103000 \\
Catchment area $\left(\mathrm{km}^{2}\right)$ & 0.58 & 0.30 \\
\hline
\end{tabular}

sensitive and non-linear response to changes in climate, owing to the discontinuities in water behaviour both at $0^{\circ} \mathrm{C}$ (ice freezing/melting) and at $4{ }^{\circ} \mathrm{C}$ (density maximum of fresh water), and to the fact that ice and snow cover can effectively hamper fluxes of light, heat, matter and momentum between the atmosphere and the water column (Saloranta et al., 2009). Thus the projected climate change may have an especially profound impact on the chemistry and ecology of lakes in colder regions (Livingstone and Dokulil, 2001; Järvinen et al., 2002; Weyhenmeyer et al., 2008). Climate change projections for Finland based on six general circulation models (GCMs) give a range of increases for mean annual temperature between $2.4^{\circ} \mathrm{C}$ and $7.4^{\circ} \mathrm{C}$ and for annual precipitation of $6 \%$ to $34 \%$ between the baseline period 1961-1990 and the period 2070-2099 (Jylhä et al., 2004). The predicted future increase in wind speed is also expected to increase the input of mixing energy to lakes in Finland (Saloranta et al., 2009).

The stratification cycle and heat balance of lakes can be manipulated by artificially increasing the input of mixing energy (Lydersen et al., 2008). Controlled, experimental manipulation of mixing processes can thus open for the direct effects of climate change on lake ecosystems, in situ, in real time, and at the whole-ecosystem scale. Here we report results of a thermocline manipulation experiment (THERMOS) carried out in the small humic lake Halsjärvi (southern Finland) during 2003-2007. The aims of this experiment were to:

- Apply a thermodynamic model (MyLake, Saloranta and Andersen 2007) to the collected data and simulate the effect of climate change scenarios. The model results were also used for the design of the manipulation experiment.

- Quantify the effects of controlled thermocline manipulation on biogeochemical cycles (including $\mathrm{Hg}$ ), foodweb structure and productivity, and biodiversity in dystrophic systems.
- Compare results of the Finnish experiment with the Norwegian THERMOS lake manipulation experiment, where a clear-watered deep lake has been manipulated (Lydersen et al., 2008).

The focus in this paper is on describing the experimental design, use of thermodynamic modelling for setting the manipulation targets, and observed changes in main physical and chemical variables. Results on changes in biota and mercury processes are described elsewhere (Rask et al., 2010; Verta et al., 2010).

\section{Materials and methods}

The approach of this study was a paired whole-lake manipulation experiment in which one lake (Halsjärvi) was manipulated while the other (Valkea-Kotinen) served as a reference. Modelling was an integral component of the design, where the thermodynamic MyLake model (Saloranta and Andersen, 2007) was used for both predicting the impacts of climate scenarios and for determining the manipulation target of the experiment.

\subsection{Site descriptions}

The reference site Valkea-Kotinen is a small headwater catchment situated in a remote, unmanaged forested area in southern Finland (Table 1). The catchment is in a protected conservation area and only receives background levels of air pollution. The catchment has an area of $0.30 \mathrm{~km}^{2}$ and the lake elevation is $156 \mathrm{~m}$ a.s.l. Typical of glaciated boreal, the catchment contains areas of forested mineral soil (higher elevations), peatland (lower elevations and adjacent to the lakes and streams) and a discharge lake with a stream. The mineral soils in the catchments are predominately Podzols developed in shallow glacial drift (till) deposits (Starr and Ukonmaanaho, 2001; Holmberg et al., 2006). The forest cover consists mainly of old-growth mixed stands of Norway spruce and deciduous species (birch and aspen) with large individuals of Scots pine present. The lake $\left(0.041 \mathrm{~km}^{2}\right)$ in the Valkea-Kotinen catchment has a mean depth of $3 \mathrm{~m}$ and a single discharge, and is typical for the large number of small lakes in these boreal forested regions. Valkea-Kotinen is one of the most intensively studied small catchments in Finland, with extensive catchment and limnological data available (e.g. Keskitalo et al., 1998; Starr and Ukonmaahano, 2001; Holmberg et al., 2006; Futter et al., 2009). The catchment is part of the UN/ECE ICP-Forests and ICP IM monitoring program in Finland (Starr and Ukonmaanaho, 2001).

The lake Halsjärvi was selected from the same area to be as similar as possible to Valkea-Kotinen regarding the main characteristics (Table 1). The distance between lakes is $4.5 \mathrm{~km}$. The catchment of Halsjärvi has similar Podzolic soils, till deposits and forest vegetation as Valkea-Kotinen, although the lake itself is surrounded by the glacial-fuvial 
Table 2. Chemical characteristics of lakes Halsjärvi (experimental lake) and Valkea-Kotinen (reference lake). Values are whole-lake volumeweighted mean concentrations and standard deviation based on samples collected during the ice-free season in May to October each year. Pre-treatment (pre) 2003-2004; treatment 2005-2006 (treat); post-treatment 2007 (post).

\begin{tabular}{|c|c|c|c|c|c|c|c|c|c|c|c|c|c|c|c|c|c|c|c|}
\hline & & \multicolumn{3}{|c|}{$\begin{array}{c}\text { Halsjärvi } \\
\text { pre }^{1}\end{array}$} & \multicolumn{3}{|c|}{$\begin{array}{c}\text { Valkea-Kotinen } \\
\text { pre }^{2}\end{array}$} & \multicolumn{3}{|c|}{$\begin{array}{c}\text { Halsjärvi } \\
\text { treat }\end{array}$} & \multicolumn{3}{|c|}{$\begin{array}{l}\text { Valkea-Kotinen } \\
\text { treat }^{3}\end{array}$} & \multicolumn{3}{|c|}{$\begin{array}{c}\text { Halsjärvi } \\
\text { post }\end{array}$} & \multicolumn{3}{|c|}{$\begin{array}{c}\text { Valkea-Kotinen } \\
\text { post }^{3}\end{array}$} \\
\hline & & Mean & Std & $\mathrm{n}$ & Mean & Std & $\mathrm{n}$ & Mean & Std & $\mathrm{n}$ & Mean & Std & $\mathrm{n}$ & Mean & Std & $\mathrm{n}$ & Mean & Std & $\mathrm{n}$ \\
\hline Cond & $\begin{array}{l}\mu \mathrm{S} \mathrm{cm}-1, \\
25^{\circ} \mathrm{C}\end{array}$ & 62.0 & 8.8 & 40 & 28.3 & 0.6 & 52 & 49.1 & 1.5 & 46 & 27.3 & 0.6 & 48 & 51.8 & 1.4 & 13 & 28.5 & 0.7 & 19 \\
\hline $\mathrm{pH}^{4}$ & & 6.37 & & 40 & 5.35 & & 54 & 6.62 & & 46 & 5.24 & & 48 & 6.59 & & 13 & 5.06 & & 19 \\
\hline $\mathrm{Ca}$ & $\mathrm{mg} \mathrm{l}^{-1}$ & 6.2 & 0.5 & 29 & 2.41 & 0.06 & 6 & 5.4 & 0.2 & 46 & 2.23 & 0.07 & 10 & 5.2 & 1.0 & 13 & 2.29 & 0.05 & 7 \\
\hline $\mathrm{Mg}$ & $\mathrm{mg} \mathrm{l}^{-1}$ & 1.23 & 0.05 & 29 & 0.70 & 0.02 & 6 & 1.10 & 0.02 & 46 & 0.64 & 0.08 & 10 & 1.21 & 0.31 & 13 & 0.71 & 0.01 & 7 \\
\hline $\mathrm{Mn}^{5}$ & $\mathrm{mg} \mathrm{l}^{-1}$ & 0.061 & 0.017 & 29 & 0.017 & 0.001 & 6 & 0.025 & 0.007 & 46 & 0.014 & 0.001 & 4 & 0.032 & 0.005 & 13 & NA & & \\
\hline $\mathrm{Fe}$ & $\mathrm{mg} \mathrm{l}^{-1}$ & 3.13 & 0.79 & 29 & 0.44 & 0.10 & 6 & 1.46 & 0.33 & 46 & 0.42 & 0.05 & 9 & 1.52 & 0.39 & 13 & 0.36 & 0.05 & 6 \\
\hline $\mathrm{Cl}$ & $\mathrm{mg} \mathrm{l}^{-1}$ & 1.61 & 0.10 & 29 & 1.37 & 0.08 & 6 & 1.74 & 0.11 & 46 & 1.25 & 0.18 & 10 & 1.56 & 0.12 & 13 & 1.44 & 0.09 & 7 \\
\hline $\mathrm{SO}_{4}$ & $\mathrm{mg} \mathrm{l}^{-1}$ & 9.3 & 0.8 & 29 & 5.2 & 0.5 & 6 & 8.8 & 0.3 & 46 & 4.5 & 0.5 & 10 & 9.0 & 0.6 & 13 & 5.5 & 0.4 & 7 \\
\hline $\begin{array}{l}\mathrm{N} / \mathrm{NO}_{3}+ \\
\mathrm{NO}_{2}\end{array}$ & $\mu \mathrm{g} \mathrm{l}{ }^{-1}$ & 47 & 27 & 29 & 31 & 11 & 28 & 34 & 32 & 46 & 20 & 8 & 48 & 28 & 24 & 13 & 12 & 3 & 24 \\
\hline TOC $^{6}$ & $\mathrm{mg} \mathrm{l}^{-1}$ & 10.9 & 3.7 & 40 & 13.9 & 1.9 & 55 & 8.0 & 0.4 & 46 & 13.7 & 1.3 & 6 & 9.6 & 1.2 & 13 & NA & & \\
\hline Colour & $\mathrm{mg} \mathrm{Pt}^{-1}$ & 237 & 84 & 29 & 207 & 32.325 & 28 & 147 & 24 & 46 & 198 & 16 & 48 & 143 & 15 & 13 & 175 & 6 & 19 \\
\hline chl- $a$ & $\mu \mathrm{g} 1^{-1}$ & 15 & 6 & 29 & 14 & 6 & 28 & 6 & 3 & 45 & 16 & 6 & 48 & 13 & 6 & 10 & 13 & 5 & 21 \\
\hline
\end{tabular}

${ }^{1}$ In 2003 only cond, $\mathrm{pH}$, totN, totP and TOC were analysed.

2 Missing values for $1 \mathrm{~m}$ depth of $\mathrm{SO}_{4}$ and $\mathrm{Cl}$ in 2007 estimated from values from $3 \mathrm{~m}$.

${ }^{3}$ Missing values for $\mathrm{Ca}, \mathrm{Mg}, \mathrm{Na}, \mathrm{K}$ in 2007 estimated from monthly and depth-specific mean concentrations in $2000-2007$ (concentrations very stable).

${ }^{4}$ Change in $\mathrm{pH}$ estimated from $\mathrm{H}^{+}$concentrations.

5 Mn values for Valkea-Kotinen for 2006 and 2007 only available from $0.1 \mathrm{~m}$ depth. For this reason the results of the statistical analysis (RIA) from both lakes includes only values from 2004 and 2005 .

6 Only values for surface layer used in RIA for both lakes.

sand deposits. Both lakes are shallow, highly humic and oligotrophic (Table 2), and have comparable levels of total organic carbon (TOC) and main nutrients. Valkea-Kotinen is, however, more acidic than Halsjärvi.

\subsection{MyLake model application and scenario analysis}

The one-dimensional MyLake lake simulation model (Saloranta and Andersen, 2007) was used to simulate the daily vertical distribution of lake water temperature and thus density stratification, as well as evolution of seasonal lake ice and snow cover. MyLake was coupled with automatic model calibration, uncertainty- and sensitivity analysis tools (Fourier Amplitude Sensitivity Test (FAST); Markov Chain Monte Carlo (MCMC) simulation). The model MyLake was setup and calibrated at the reference lake Valkea-Kotinen, the manipulation lake Halsjärvi and the larger Pääjärvi lake, and both model sensitivity tests and model runs with climate change scenarios were carried out. The daily meteorological time series representing the future projected climate (20712100) and the present climate (control period, 1961-1990) at Lammi region were obtained from a regional climate model (RCAO model, Rossby Center, Sweden; Jones et al., 2004;
Räisänen et al., 2004). Two different global general circulation models (GCMs) ECHAM4 and HadAM3, were used for providing the lateral atmospheric boundary condition forcing for the RCAO model. Furthermore, two different greenhouse gas emission scenarios, A2 and B2 (IPCC 2001; generally less greenhouse gas emissions in $\mathrm{B} 2$ than in $\mathrm{A} 2$ scenario) were used in RCAO model simulations. A detailed description on the model calibration and scenario results is given in Saloranta et al. (2009).

\subsection{Experimental design}

The MyLake model was used already in the planning phase of the manipulation experiment to select the target depth for lowering of the thermocline. The primary objective with the thermocline manipulation was to simulate projected future increase in the open water season lake mean temperature (i.e. heat content) in the end of the 21 st century due to climate change. Thermocline manipulation is the only reasonable way to increase the whole-lake temperature by the needed amount, as direct heating of the lake water would be prohibitively expensive and technically very difficult to carry out. Based on the model simulations, the manipulation target 

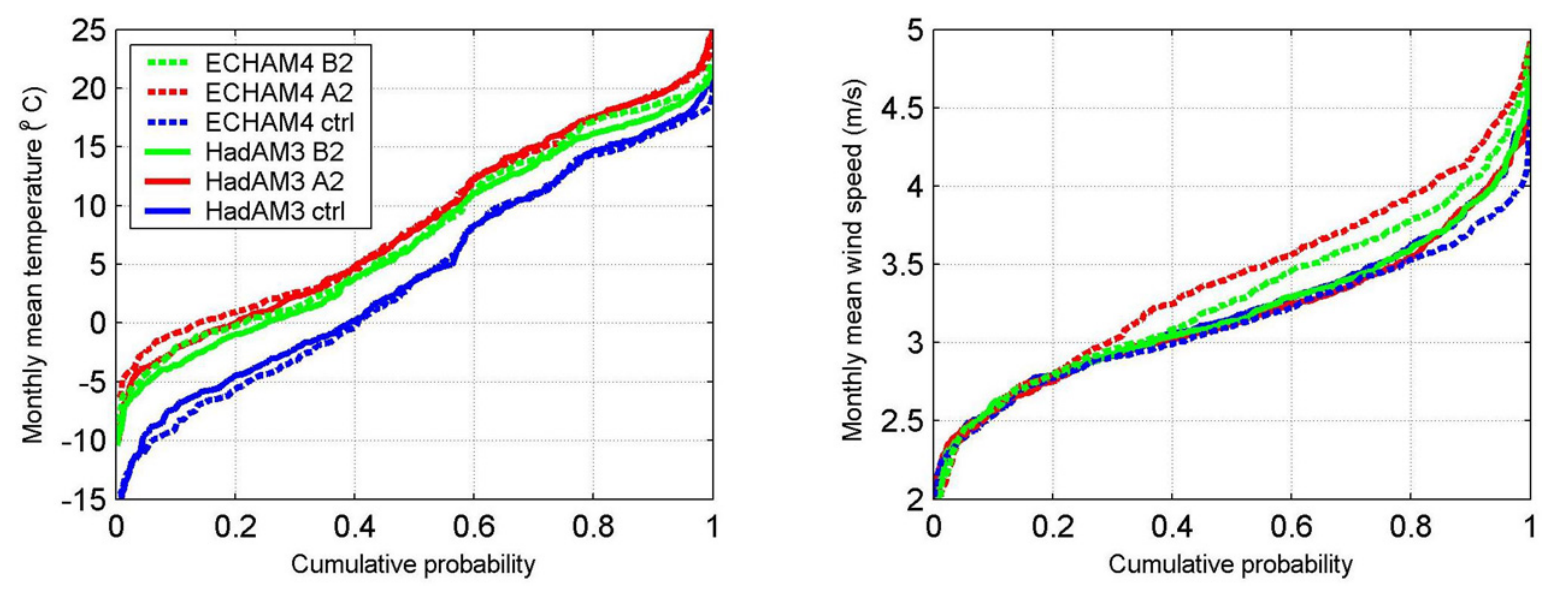

Fig. 1. Simulated changes in cumulative probabilities of monthly mean temperatures and wind speeds in the RCAO climate model simulations for Valkea-Kotinen, with both A2 and B2 scenarios as well as with both HadAM3 and ECHAM4 general circulation model boundary forcing (modified from Saloranta et al., 2009).

was set to a lowering of the thermocline in Halsjärvi with $1.5 \mathrm{~m}$, to a mean depth of about $3 \mathrm{~m}$. A comparison of the heat content increases in the manipulation experiment and in the simulated future climate is presented and discussed in more details in Sect. 3.2. As the local monthly mean wind speeds are not expected to increase very much in the climate model projections (Fig. 1), the long-term mean thermocline depth is not expected to undergo as dramatic changes as in the manipulation experiment. However, the manipulation experiment indicates a representative scenario for changes in single extreme years or changes in the lake wind exposure, e.g. due to forest fire or clear-cut (see Fee et al., 1996; Xenopoulus and Schindler, 2001).

A modified commercial aeration equipment (MIXOX, Water-Eco Ltd, Finland) was used for manipulating the thermocline depth. The deepening of the thermocline was accomplished by means of an electrically-driven propeller positioned at $1.5 \mathrm{~m}$ depth below a raft anchored at the deepest point of the lake (Fig. 2). The equipment had a maximum pumping capacity of $15000 \mathrm{~m}^{3} \mathrm{~d}^{-1}(0.6 \mathrm{~kW})$. After a testing and modification phase in 2004, the MIXOX equipment was installed in lake Halsjärvi after ice-off in early May 2005. The mixing took place from May to September in 2005 and 2006, with background monitoring in 2003-2004 and 2007. The modified equipment allowed a well controlled manipulation of the thermocline depth and heat content of the lake (Sect. 3.2).

\subsection{Sampling methods}

The lakes were sampled once a week in 2004-2006, biweekly in 2007 during the open water season, and once a month during the winter period. Water samples were taken from the middle of the lake at the deepest point. Temperature and oxygen profiles were measured with $0.5 \mathrm{~m}$ intervals, and other variables as integrated samples for three depths accord-

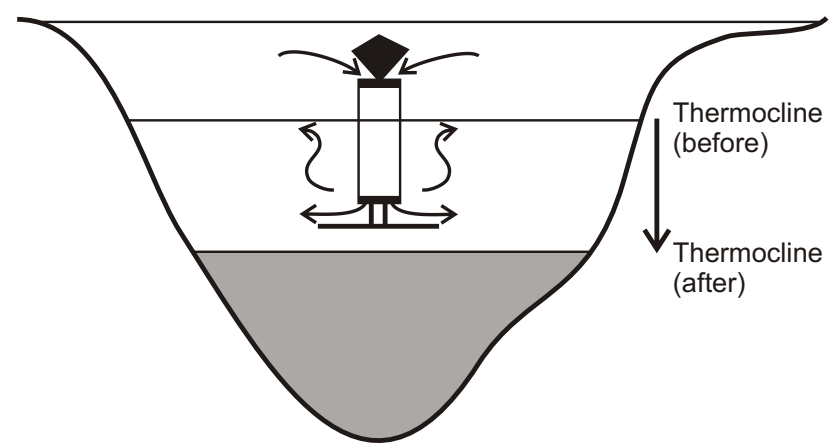

Fig. 2. The experimental design in lake Halsjärvi using the modified aeration equipment.

ing to the currently observed stratification of the lake (i.e., epi-, meta- and hypolimnion). At the reference lake ValkeaKotinen also samples from the outlet of the lake are monitored using frequencies varying from weekly to monthly during the year. Samples were analysed for $\mathrm{Ca}^{2+}, \mathrm{Mg}^{2+}, \mathrm{K}^{+}$, $\mathrm{Na}^{+}, \mathrm{Cl}^{-}, \mathrm{SO}_{4}^{2-}, \mathrm{NO}_{3}^{-}, \mathrm{NH}_{4}^{+}$, totP, totN, total organic carbon (TOC), colour, chl- $a, \mathrm{pH}$, conductivity and Gran alkalinity (Table 2) in the laboratories of the Lammi Biological Station (University of Helsinki) and Finnish Environment Institute, using standardised methods (SFS standards). Conductivity was measured conductometrically with temperature compensating cell. The value of $\mathrm{pH}$ was obtained electrometrically at $25^{\circ} \mathrm{C}$ with a pH meter, and alkalinity was measured by Gran-titration. Base cations $(\mathrm{Ca}, \mathrm{Mg}, \mathrm{Na}, \mathrm{K})$, iron $(\mathrm{Fe})$ and manganese (Mn) were measured by flame-AAS. Some analysis of $\mathrm{Fe}$ and $\mathrm{Mn}$ were determined colorimetrically after oxidation with $\mathrm{K}_{2} \mathrm{~S}_{2} \mathrm{O}_{8}$. Sulphate $\left(\mathrm{SO}_{4}\right)$ and chloride $(\mathrm{Cl})$ were measured by ion chromatography (Dionex). Total phosphorus (totP, non-filtered) and total nitrogen (totN, non-filtered) were analysed by FIA Lachat with persulphate digestion 


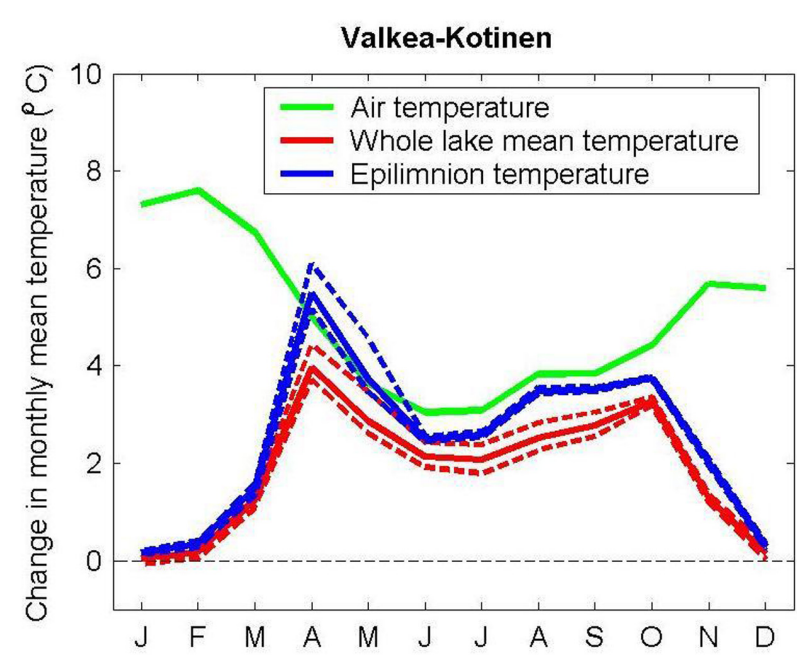

Fig. 3. Simulated change in monthly mean air, whole lake, and epilimnion ( $0.5 \mathrm{~m}$ depth) temperatures between control (19611990) and A2 (2071-2100) scenarios with the ECHAM4 forcing in Valkea-Kotinen. The first simulation years 1961 and 2071 are not included in the means. The thick solid lines denote the median, and the dashed lines the $90 \%$ credible intervals of the 200 simulations conducted in the uncertainty analysis, where parameter values sets were re-sampled from the parameter chain estimated in the MCMC simulation (modified from Saloranta et al., 2009).

(Koroleff, 1979). The sum of nitrate-nitrite $\left(\mathrm{N} / \mathrm{NO}_{3}+\mathrm{NO}_{2}\right)$ and ammonium $\left(\mathrm{N} / \mathrm{NH}_{4}\right)$ were measured by FIA Lachat (Wood et al., 1967; Solorzano, 1969). TOC was measured by Shimadzu TOC-5000A with high-temperature combustion, and water colour $\left(\mathrm{mg} \mathrm{Pt}^{-1}\right)$ was measured by Shimadzu UV2100 spectrophotometer at $420 \mathrm{~nm}$ with platinum cobalt standards. Chlorophyll- $a$ (chl- $a$ ) was analysed by Shimadzu UV2100 spectrophotometer using hot ethanol as a solvent.

Main nutrients, $\mathrm{pH}$ and conductivity were analysed most frequently in both lakes, while the variables assumed to be more conservative (main cations and anions) were given less attention in the reference lake Valkea-Kotinen (Table 2). Background sampling $(n=11)$ was done in Halsjärvi already in 2003 for selected variables (pH, conductivity, totN, totP, TOC) but was not included in the statistical analysis. Time series of temperature profiles were recorded by thermistor chains installed at $0.5 \mathrm{~m}$ intervals in the lakes. Whole-lake volume-weighted average concentrations were calculated using the measured concentration and estimated lake volume for each compartment. Due to technical and logistic problems some analyses were missing particularly in the reference lake Valkea-Kotinen. Assumptions made in the calculations are documented in Table 2.

Only results on main chemical and physical variables are dealt with in the present paper. Methods and results regarding the intensive measurements on $\mathrm{Hg}$ and lake biota are described in Rask et al. (2010) and Verta et al. (2010).

\subsection{Statistical analysis}

Randomized Intervention Analysis (RIA, Carpenter et al., 1989) was used to test for statistical significance of changes that can be ascribed to the manipulation. RIA method is designed specifically for paired-ecosystem experiments, in which one ecosystem is manipulated while the other serves as a reference. The method does not assume that the two lakes are identical, but rather that both lakes respond similarly to natural fluctuations. The method requires a pretreatment monitoring period during which the inherent difference between the lakes is determined, and then a treatment monitoring period. The method tests the hypothesis that the difference between the lakes changed when the treatment was initiated. In this study RIA was used to compare paired, chronologically-ordered samples for the four-year data record (one year pre-treatment, two years treatment, one year post-treatment) from the manipulated (Halsjärvi) and reference (Valkea-Kotinen) lakes. The RIA was done separately for the pre- and post-treatment periods. For the pretreatment period only values for the year 2004 were used.

\section{Results}

\subsection{MyLake modelling: impacts of climate change scenarios on lake thermodynamics}

The MyLake simulation results for Valkea-Kotinen (Fig. 3) showed that the whole-lake monthly mean temperature in the A2 scenario increased in April-October by $1.4-4.4^{\circ} \mathrm{C}$ compared to the control period (all such value intervals in this section correspond to the minimum and maximum of the $90 \%$ credibility intervals of the results with HadAM3 and ECHAM4 forcings), the largest increase being in April, corresponding to the large decrease in the probability of ice cover in March-April $(-0.2$ to -0.9$)$. A similar larger drop in the probability of ice cover was also seen in November. The mean length of the ice covered period was shortened by $56-89$ days. The simulated water temperature increase was largest in the epilimnion, being $4.6-6.1$ and $3.5-4.6^{\circ} \mathrm{C}$ higher in April and May, respectively, in the A2 scenario compared to the control period. Similarly, in June-November the simulated epilimnion temperature in A2 scenario was $1.9-3.8^{\circ} \mathrm{C}$ higher, while in December-February almost the same $\left(<0.45^{\circ} \mathrm{C}\right.$ difference $)$, compared to the control period. In the hypolimnion the simulated difference between A2 scenario and control period was largest in April and October $\left(1.2-2.6^{\circ} \mathrm{C}\right.$ difference), and smallest in December-February ( $<0.4{ }^{\circ} \mathrm{C}$ difference).

The simulated mean monthly pycnocline depth (closely related to thermocline depth; calculated as density gradient weighed mean of the depth) increased from 1 to $3 \mathrm{~m}$ in May-September in the control scenario and does not seem not to undergo very dramatic changes in the 

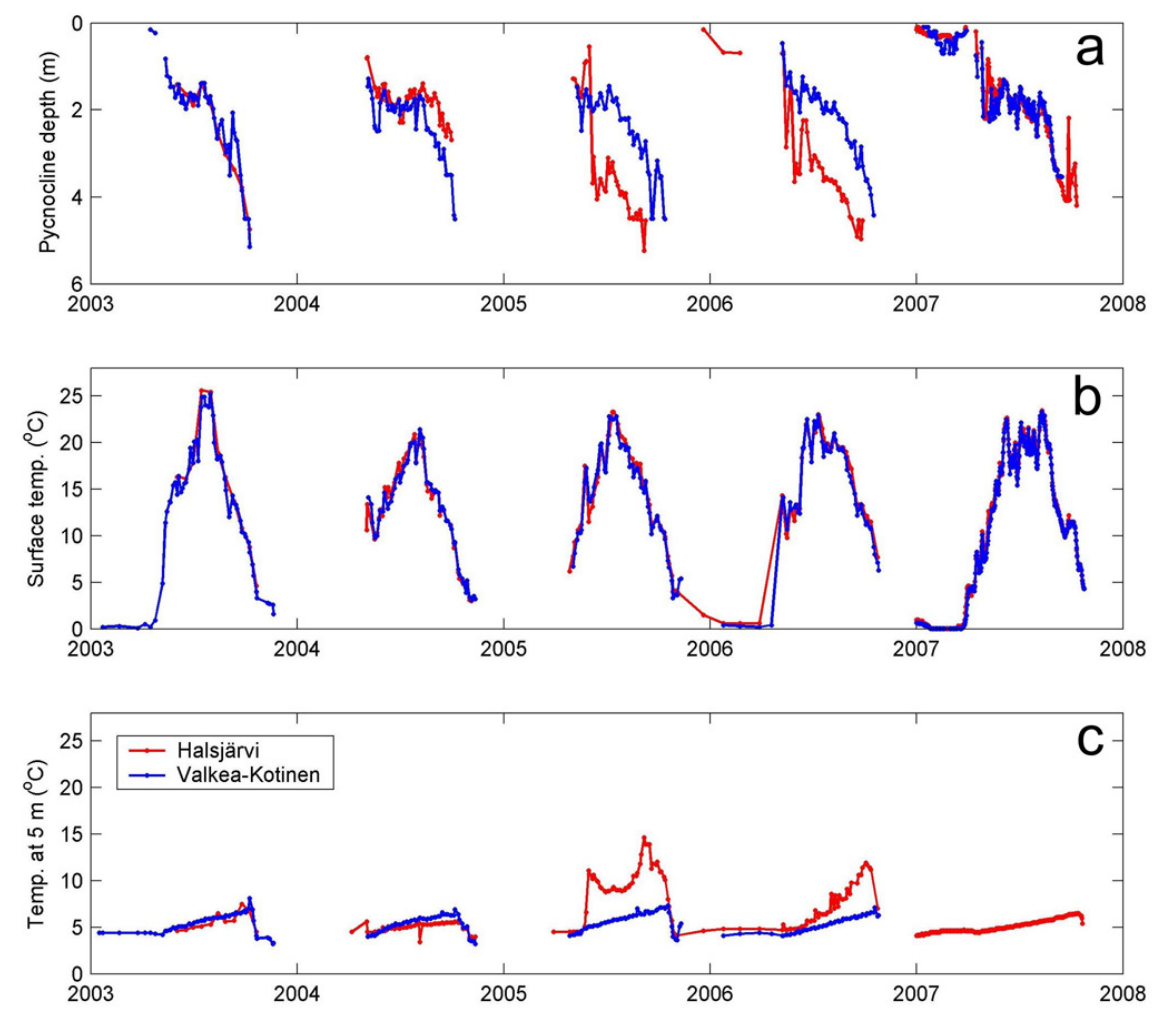

Fig. 4. Seasonal development of (a) pycnocline depth as well as (b) surface and (c) near bottom (5 m) temperatures in lakes Halsjärvi and Valkea-Kotinen. The artificial mixing (lake manipulation experiment) was conducted in Halsjärvi in 2005-2006. Observations are denoted by dots.

projected future climate as the pycnocline was at largest $0.10-0.43 \mathrm{~m}$ deeper in May and $0.05-0.47 \mathrm{~m}$ shallower in September (A2 scenario) compared to the control period (see Saloranta et al., 2009).

\subsection{Observed changes in thermal properties: heat budgets and stratification patterns}

Figures 4 and 5 show the observed seasonal evolution of pycnocline depth, surface and near bottom temperatures, interpolated temperature profiles (contour plots), as well as heat content in the manipulated lake Halsjärvi and in the reference lake Valkea-Kotinen. When compared with the reference years 2003-2004 and the results of the reference lake, the experimental mixing caused a $1.5-2 \mathrm{~m}$ deepening of the thermocline (pycnocline) in summer seasons 2005 and 2006, as originally planned (Fig. 4). Furthermore, the manipulation did not affect surface temperatures significantly but increased the near-bottom temperatures by up to $8^{\circ} \mathrm{C}$ (Figs. 4c and 5a, b).

As shown in Fig. 6, the MyLake model predicted increased heat content of on average $9.5 \mathrm{MJ} \mathrm{m}^{-3}$ (equivalent to $2.3^{\circ} \mathrm{C}$ increase in the water mass temperature) in the period from late May to late October (i.e. the manipulation period) in 2071-2100 compared to 1961-1990, when forced with meteorological time series from the regional climate model $\mathrm{RCAO}$, assuming the A2 emission scenario and two different general circulation model boundary forcings (ECHAM4 and HadAM3). The increased mean heat content in the manipulation experiment was $11.1 \mathrm{MJ} \mathrm{m}^{-3}$ (equivalent to $2.6^{\circ} \mathrm{C}$ increase in the water mass temperature) in the same period, indicating that the lake manipulation experiment seemed to represent the average simulated future increase in heat content in the summer/autumn season quite well.

The seasonal evolution of this warming was different between the simulated and manipulated cases. In the simulated future scenario the largest warming was on average seen early and late in the open water season, in May and October, while in the manipulation experiment the warming was largest in the mid-summer in July. However, taking into account the two different GCM boundary forcing scenarios as well as the uncertainty in MyLake model parameters, the seasonal evolution of warming in the manipulation experiment was still within the $95 \%$ credible interval of the simulated year-to-year warming (Fig. 6). 

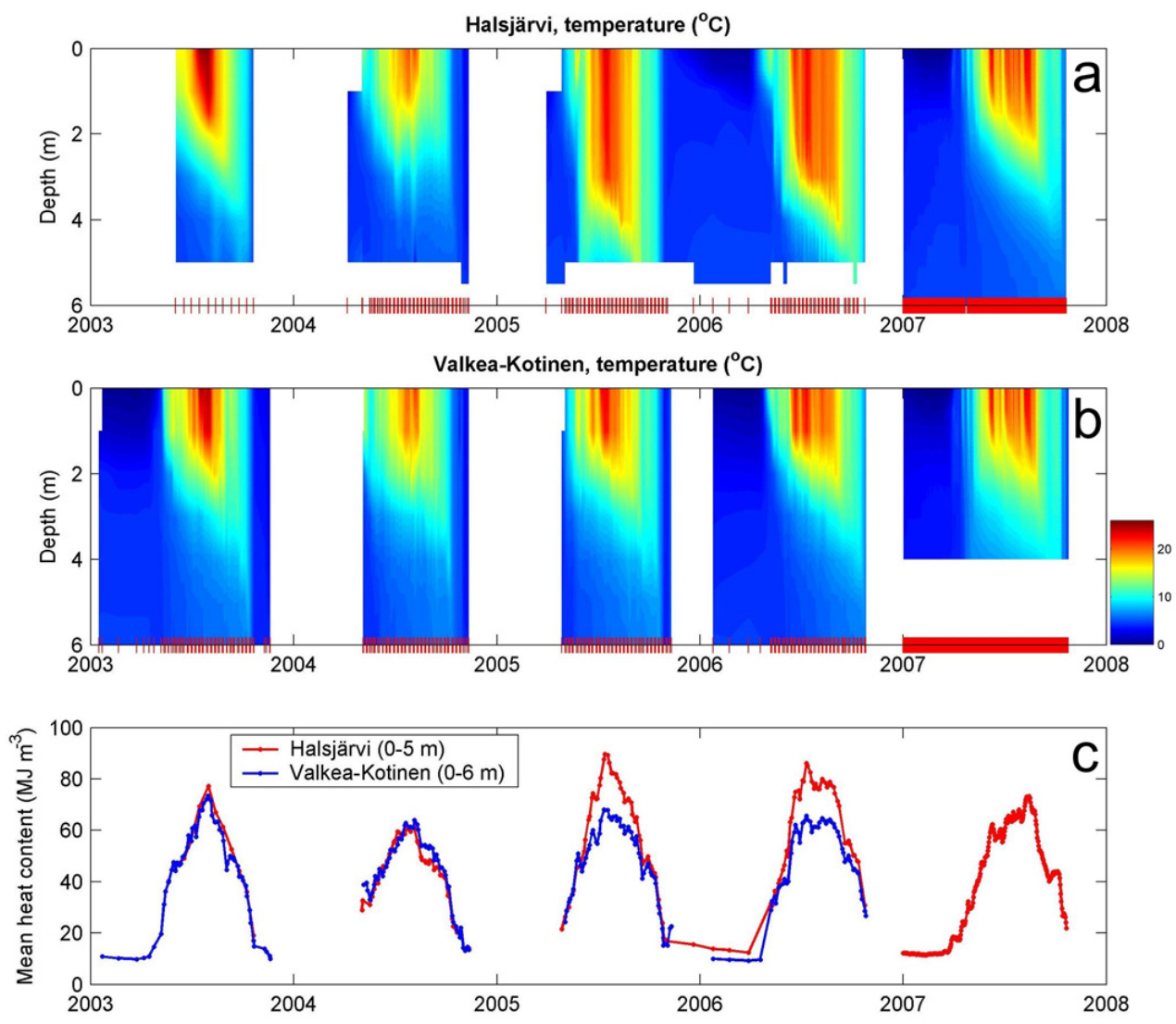

Fig. 5. Interpolated seasonal development of temperature in lakes (a) Halsjärvi and (b) Valkea-Kotinen based on observed profiles (denoted by the ticks on the x-axis); (c) seasonal development in mean lake heat content in Halsjärvi (0-5 m; red line) and Valkea-Kotinen (0-6 m; blue line). The artificial mixing (lake manipulation experiment) was conducted in Halsjärvi in 2005-2006.

\subsection{Observed changes in water chemistry}

Volume-weighted chemical characteristics for the pretreatment (2003-2004), treatment (2005-2006) and posttreatment period (2007) for Halsjärvi and Valkea-Kotinen are shown in Table 2. All values refer to the period MayOctober for the different years. Also shown are the differences in concentrations in Halsjärvi relative to ValkeaKotinen and change in difference for the treatment relative to pre- and post-treatment years (Table 3 ). The change due to treatment was tested by Randomized Intervention Analysis (RIA, Carpenter et al., 1989). Since it was assumed that the treatment could cause some "carry-over" effects to the post-treatment period (2007), the analysis was done separately for the pre- and post-treatment periods. Note that in the RIA analysis only values for the year 2004 are included in the pre-treatment period (Table 3).

Both lakes are shallow, highly humic and oligotrophic (Table 2). TotP concentrations were about $9-15 \mu \mathrm{g} 1^{-1}$ and TOC 11-14 $\mathrm{mg} \mathrm{Cl}^{-1}$. Halsjärvi has higher concentrations of main cations $\left(6.2 \mathrm{mg}^{-1}\right.$ Cavs. $2.4 \mathrm{mg}^{-1} \mathrm{Ca}$ in Valkea-Kotinen during the pre-treatment period) and consequently higher $\mathrm{pH}$ and conductivity. A typical phenomenon for this type of small humic boreal lakes is the strong regulation of oxic conditions by the thermal stratification patterns. Due to warm weather after spring ice melt in 2004, 2005 and again in 2006 the spring overturn was incomplete and both the experimental lake Halsjärvi and the reference lake Valkea-Kotinen exhibited anoxic conditions in the hypolimnion from late winter through summer till autumn overturn (Fig. 7). The oxic epilimnion reached only from $1 \mathrm{~m}$ to $2.5 \mathrm{~m}$ depth in Halsjärvi during summer 2004, but because of the experimental mixing and consequent changes in thermal stratification from $3.5 \mathrm{~m}$ to near $5 \mathrm{~m}$ during summers 2005 and 2006. At the onset of the mixing treatment in early June 2005 the mixing was too effective for a couple of days, but after correction of mixing intensity the anoxic conditions near the bottom were redeveloped. The less effective mixing is clearly seen as a shallower oxic layer in 2006 compared to 2005 . The reference lake Valkea-Kotinen did not show significant year to year variation with the exception of a better spring overturn and gain of oxic conditions through the whole water mass in spring 2007 (Fig. 7). 
Table 3. Changes in chemical characteristics of lakes Halsjärvi (Hals, experimental lake) and Valkea-Kotinen (Valk, reference lake) in the treatment period (treat) compared with the pre- and post-treatment conditions. Values are whole-lake volume-weighted mean concentrations based on samples collected during the ice-free season in May to October each year. Pre-treatment (pre) 2003-2004; treatment 2005-2006 (treat); post-treatment 2007 (post). Also shown are differences in concentrations in Halsjärvi relative to Valkea-Kotinen (Hals-Valk, years 2004-2007 according to samples ordered for RIA analyses), and change in difference for the treatment (treat-pre) and post-treatment (treatpost) years. The change ascribable to treatment was tested by Random Intervention Analysis (RIA). The RIA was carried out using values only from 2004 for the pre-treatment period. Statistical significance: NS not significant; $p<0.1 ; p<0.05$; $p<0.01$; NA not available. See Table 2 regarding number of samples and estimations made regarding missing values.

\begin{tabular}{|c|c|c|c|c|c|c|c|c|c|c|c|c|}
\hline & & \multicolumn{2}{|c|}{ Treat-pre } & \multicolumn{2}{|c|}{ Treat-post } & \multicolumn{3}{|c|}{ Hals-Valk } & \multirow[t]{2}{*}{ treat-pre } & \multirow[t]{2}{*}{ treat-post } & \multicolumn{2}{|c|}{ RIA sign } \\
\hline & & Hals & Valk & Hals & Valk & pre & treat & post & & & treat/pre & treat/post \\
\hline Cond & $\begin{array}{l}\mu \mathrm{S} \mathrm{cm}^{-1}, \\
25^{\circ} \mathrm{C}\end{array}$ & -12.8 & -1.0 & -2.6 & -1.2 & 29.0 & 21.8 & 23.7 & -7.1 & -1.9 & $p<0.01$ & $p<0.01$ \\
\hline $\mathrm{pH}$ & & 0.25 & -0.11 & 0.03 & 0.18 & $-5.26 \times 10^{-6}$ & $-5.62 \times 10^{-6}$ & $-7.24 \times 10^{-6}$ & $-3.55 \times 10^{-7}$ & $1.62 \times 10^{-6}$ & NS & $p<0.05$ \\
\hline $\mathrm{Ca}$ & $\mathrm{mg} \mathrm{l}^{-1}$ & -0.89 & -0.18 & 0.18 & -0.05 & 3.83 & 3.1 & 2.9 & -0.72 & 0.2 & $p<0.01$ & NS \\
\hline $\mathrm{Mg}$ & $\mathrm{mg} \mathrm{l}^{-1}$ & -0.129 & -0.053 & -0.111 & -0.063 & 0.537 & 0.471 & 0.508 & -0.066 & -0.037 & $p<0.01$ & NS \\
\hline $\mathrm{K}$ & $\mathrm{mg} \mathrm{l}^{-1}$ & 0.058 & 0.003 & 0.055 & 0.017 & 0.564 & 0.619 & 0.581 & 0.055 & 0.038 & $p<0.01$ & $p<0.01$ \\
\hline $\mathrm{Na}$ & $\mathrm{mg} \mathrm{l}^{-1}$ & -0.029 & -0.041 & -0.088 & -0.018 & 0.594 & 0.608 & 0.67 & 0.014 & -0.065 & NS & $p<0.01$ \\
\hline $\mathrm{Mn}$ & $\mathrm{mg} \mathrm{l}^{-1}$ & -0.035 & -0.002 & -0.007 & NA & 0.044 & 0.009 & NA & -0.035 & NA & $p<0.1$ & NA \\
\hline $\mathrm{Fe}$ & $\mathrm{mg} \mathrm{l}^{-1}$ & -1.7 & -0.016 & -0.1 & 0.06 & 2.70 & 1.1 & 1.4 & -1.63 & -0.29 & $p<0.01$ & $p<0.05$ \\
\hline $\mathrm{Cl}$ & $\mathrm{mg} \mathrm{l}^{-1}$ & 0.1 & -0.1 & 0.2 & -0.2 & 0.25 & 0.51 & 0.14 & 0.25 & 0.4 & $p<0.01$ & $p<0.01$ \\
\hline $\mathrm{SO}_{4}$ & $\mathrm{mg} \mathrm{l}^{-1}$ & -0.5 & -0.8 & -0.2 & -1.1 & 4.13 & 4.3 & 3.4 & 0.17 & 0.9 & NS & $p<0.01$ \\
\hline $\begin{array}{l}\mathrm{N} / \mathrm{NO}_{3}+ \\
\mathrm{NO}_{2}\end{array}$ & $\mu \mathrm{g} \mathrm{l}{ }^{-1}$ & -13.4 & -11.1 & 6.0 & 8.2 & 15.8 & 13.4 & 14.7 & -2.4 & -1.3 & NS & NS \\
\hline $\mathrm{N} / \mathrm{NH}_{4}$ & $\mu g \mathrm{l}^{-1}$ & -54.3 & -7.8 & 3.4 & 18.0 & 49 & 2.2 & 13.3 & -47 & -11.1 & $p<0.01$ & $p<0.05$ \\
\hline Alk & $\mathrm{mmol} \mathrm{l}^{-1}$ & -0.077 & -0.001 & -0.019 & 0.015 & 0.24 & 0.16 & 0.19 & -0.08 & 0.0 & $p<0.01$ & $p<0.01$ \\
\hline totN & $\mu \mathrm{gl}^{-1}$ & -214.6 & 2.2 & -7.9 & 18.3 & 3 & -150.9 & -125.1 & -154 & -25.8 & $p<0.01$ & $p<0.05$ \\
\hline totP & $\mu \mathrm{gl}^{-1}$ & 0.3 & 0.1 & 1.2 & -2.8 & -7.6 & -6.4 & -9.0 & 1.17 & 2.6 & NS & $p<0.1$ \\
\hline TOC & $\mathrm{mg} \mathrm{l}^{-1}$ & -2.9 & NA & -1.5 & NA & 1.0 & -5.3 & -2.8 & -6.3 & -2.5 & $p<0.01$ & $p<0.01$ \\
\hline Colour & $\mathrm{mg} \mathrm{Ptl} 1^{-1}$ & -89.4 & -9.1 & 4.5 & 22.6 & 30 & -51.3 & -31.3 & -81 & -20.0 & $p<0.01$ & $p<0.01$ \\
\hline chl- $a$ & $\mu \mathrm{gl}^{-1}$ & -8.2 & 1.8 & -6.7 & 2.8 & 0.5 & -9.5 & 0.3 & -10 & -9.8 & $p<0.01$ & $p<0.01$ \\
\hline
\end{tabular}

The manipulation caused changes in several other water quality variables as well (Tables 2 and 3, Fig. 8). The largest changes were observed for the nitrogen species tot $\mathrm{N}$ and $\mathrm{NH}_{4}$, where a clear statistically significant decline was observed compared with the pre-treatment period (Table 3, Fig. 8a, c). The change observed in Halsjärvi was -215 and $-54 \mu \mathrm{g}{ }^{-1}$ for totN and $\mathrm{NH}_{4}$, respectively (treatment minus pre-treatment period). Also the relative changes ascribable to treatment (i.e. differences in concentrations in Halsjärvi relative to Valkea-Kotinen) were similar (treat-pre $=-154$ and $-47 \mu \mathrm{g} 1^{-1}$, respectively). This was related to a similar decline in organic carbon (both TOC and colour), which also was statistically significant $(p<0.01)$ compared with both pre-treatment $\left(-6.3 \mathrm{mgl}^{-1},-81 \mathrm{mg} \mathrm{Pt}^{-1}\right)$ and posttreatment periods $\left(-2.5 \mathrm{mg} \mathrm{l}^{-1},-20 \mathrm{mg} \mathrm{Pt}^{-1}\right)$. The change in $\mathrm{NO}_{3}$ was, however, not statistically significant (Table 3 ). $\mathrm{NO}_{3}$ concentrations in Halsjärvi decreased rapidly after iceoff in May during all years (Fig. 8e). For tot-P the observed increase was significant $(p<0.1)$ only relative to the posttreatment conditions (Table 3 ).

Sedimentation traps installed in Halsjärvi indicated that the gross sedimentation of dry matter increased four fold from $12.7 \mathrm{~g} \mathrm{~m}^{-2}$ and $11.3 \mathrm{~g} \mathrm{~m}^{-2}$ in 2004 and 2007 to $55.7 \mathrm{~g} \mathrm{~m}^{-2}$ in 2005 (six week period from early July to late August, Verta et al., 2010). The increase in gross sedimen- tation can be explained by the precipitation of $\mathrm{Fe}$ and $\mathrm{Mn}$ aggregates due to mixing induced oxygenation of soluble $\mathrm{Fe}$ and $\mathrm{Mn}$ species. This is reflected also as decreased average concentrations of $\mathrm{Fe}$ and $\mathrm{Mn}$ as a result of the experiment (Table 3, Fig. 8f). The decrease in Fe during treatment was statistically significant compared with both the pre-treatment $(p<0.01)$ and post-treatment $(p<0.05)$ periods (Table 3$)$. During all anoxic periods in Halsjärvi, Fe in the hypolimnion reached high levels (but with a smaller volume in 2005, 2006 and 2007) with a drop during autumn overturn.

In the epilimnion of lake Halsjärvi there was an increase in alkalinity as well as in the concentration of $\mathrm{Fe}$ and $\mathrm{NH}_{4}$ just after the onset of the artificial mixing in summer 2005 (not shown). However, the elevated concentrations decreased within a few weeks and reached their pre-treatment levels in July. In contrast, in the hypolimnion a decline in conductivity, alkalinity, $\mathrm{NO}_{3}$ and the major cations $(\mathrm{Ca}$ and $\mathrm{Mg}$ ) was observed immediately after starting the mixing, but the pre-treatment levels were reached along the restratification of the water column. Regarding the average volume-weighted concentrations, a slight statistically significant decrease in alkalinity $\left(-0.08 \mathrm{mmoll}^{-1}, p<0.01\right)$ was observed during treatment relative to the pre-treatment period; compared with the post-treatment period a statistically significant $(p<0.01)$ stable situation was indicated 


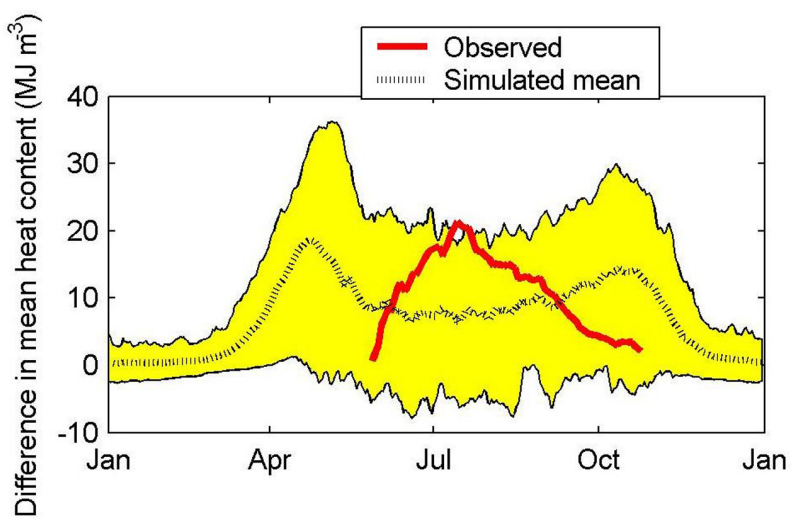

Fig. 6. Difference in the simulated yearly seasonal heat content in lake Halsjärvi $(0-5 \mathrm{~m})$ between randomly selected years of control (1961-1990) and future climate (2071-2100) simulation periods. The yellow area denotes the $95 \%$ credible interval and the black dashed line the mean of simulations in uncertainty analysis, taking into account MyLake model parameter uncertainty and two different general circulation model boundary forcings (ECHAM4 and HadAM3) for the regional climate model. The red line denotes similar mean heat content difference observed in the large-scale lake manipulation experiment between the lake Valkea-Kotinen (non-manipulated control lake) and the manipulated (artificially increased mixing) Halsjärvi in 2005-2006 (see Fig. 5). Average heat content (in $\mathrm{MJ}$ ) per $\mathrm{m}^{3}$ water is used as the unit and this is proportional to the mean temperature of lake water mass (conversion from units of $\mathrm{MJ} \mathrm{m}^{-3}$ to ${ }^{\circ} \mathrm{C}$ by dividing values on y-axis by 4.19).

(Table 3, Fig. 8b). Chlorophyll- $a$ (chl- $a$ ) showed a statistically significant decrease during treatment, compared with both the pre-treatment $\left(-10 \mu \mathrm{g} \mathrm{l}^{-1}, p<0.01\right)$ and posttreatment $\left(-9.8 \mu \mathrm{g}^{-1}, p<0.01\right)$ situation (Table 3$)$.

The RIA indicated in general consistent results for the treatment vs. pre-treatment (treat/pre) and treatment vs. posttreatment periods (treat/post, Table 3). However, the changes in concentrations were generally lower during the treatment vs. post-treatment periods.

\section{Discussion}

Predicting responses to ecosystem perturbations is among the greatest challenges to ecology. Small experimental systems often have limited power if changes in biogeochemical cycles or complex biotic relationships are studied. Whole ecosystem experiments are a powerful method for evaluating and predicting environmental change, and well-known experiments have successfully been conducted in both terrestrial and freshwater ecosystems (e.g. Carpenter et al., 1995; Schindler et al., 1996b; Wright, 1998; Lydersen et al., 2008). However, there are also serious limitations with the approach, including tradeoffs regarding replication, spatial extent and duration due to financial constraints. In addition, the natural outdoor conditions cannot be controlled. Ecosystem experiments, such as the one carried out in the present study, are therefore more useful to measure responses and their ecological significance than to test null hypotheses and their statistical significance (Carpenter et al., 1995).

A shift in climate variables such as air temperature, radiation, cloud cover, wind or humidity will influence the heat fluxes and thus alter the heat balance of lakes and rivers. The strength and persistence of the climate signal with time and depth are determined by the lakes' geographical location, landscape topography, lake morphometry, and mixing conditions (Dokulil et al., 2006; Weyhenmayer et al., 2008; Nickus et al., 2010). The MyLake simulation results for ValkeaKotinen indicated large changes in the whole-lake monthly mean temperature for the A2 scenario in April-October and a large decrease in the probability of ice cover in March-April. The simulations with ECHAM4 forcing showed generally slightly larger changes than those with HadAM3 forcing, and similarly the changes in A2 scenarios were obviously larger compared to B2 scenarios. However, the general pattern of change was much the same in all these scenarios (Sect. 3.1). Analysis of long-term data series demonstrate that changes in the thermal regime in lakes have indeed occurred during the past decades. For example, Korhonen (2006) analyzed freeze-up and break-up records of almost 90 lakes in Finland dating back to the early 19th century, and ice thickness records of about thirty lakes dating back to the 1910s. This analysis showed both a significant change towards earlier ice break-up, except for the very north of Finland, and a significant trend towards a later freeze-up, thus resulting in a shorter duration of the ice.

The extensive manipulation of the thermocline in Halsjärvi resulted in large changes in the thermodynamic properties of the lake which rather well represented the average simulated future increase in heat content in the summer/autumn season (Fig. 6). The modelled result for the A2 scenario was $9.5 \mathrm{MJ} \mathrm{m}^{-3}$ compared with the measured $11.1 \mathrm{MJ} \mathrm{m}^{-3}$ of the manipulation experiment. Although the seasonal dynamics of this warming was different between these cases, the uncertainty analysis indicated that the seasonal evolution was still within the range of year to year variability of climate warming. Although an attempt was made to make the climate change perturbation as realistic as possible using advanced thermodynamic modelling for setting the manipulation target, the design was obviously not a completely realistic simulation of the expected changes in physical conditions in the lake given the predicted large increases in air temperature. That would require heating up the water in the entire lake (combined with some mixing to ensure realistic heat distribution and simulation of predicted increases in wind speed) and would be prohibitively expensive and technically extremely challenging to carry out. On the other hand, the design is about the only relevant whole-lake manipulation that can be achieved and with which the effects of changed temperature (degree days for production etc.) can be directly measured. 

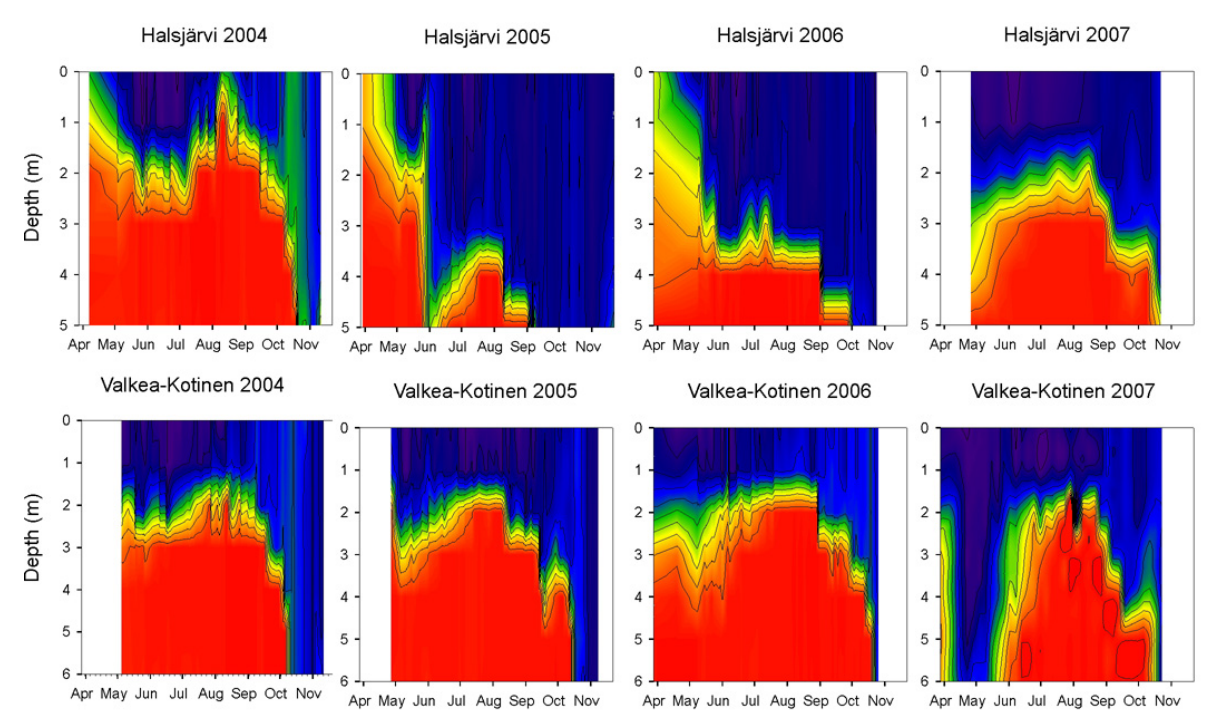

Oxygen saturation (\%)

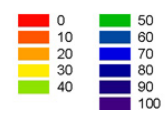

Fig. 7. Interpolated seasonal development of oxygen saturation (\%) in lake Halsjärvi (upper figures) in the reference years (2004, 2007) and in experimental years $(2005,2006)$. Lake Valkea-Kotinen (lower figures) as a reference.

The manipulation experiment indicates also a representative scenario for changes in single extreme years or changes in the lake wind exposure, due extensive forest management and forest fires. Such catchment changes have been shown to affect thermal regimes in lakes (Steedman and Kushneruik, 2000; Xenopoulos and Schindler, 2001). The average wind speed is also expected to increase somewhat according to the predictions for the study region (Fig. 1), which would tend to lower the depth of the thermocline of the lakes. This impact would however be smaller than caused by the artificial mixing. Nevertheless, the experiment provides direct evidence on how lake ecosystems may respond to future global change processes.

The artificial mixing and lowered thermocline clearly modified the oxygen stratification during the summer seasons of 2005 and 2006 in Halsjärvi in comparison to the pre- and post-treatment years as well as to Valkea-Kotinen. While the minimum oxic layer was only $1 \mathrm{~m}$ deep in 2004, mixing increased the depth of the oxic layer to $3.5 \mathrm{~m}$ in the experimental years 2005 and 2006 (Fig. 7). The expansion of the oxic water (volume) layer in Halsjärvi increased the spatial coverage of the oxic sediment surface from $<20 \%$ to $60 \%$ of the surface area of the lake (oxic-anoxic interfaces). This change in the oxygen stratification and precipitation of the $\mathrm{Fe}$ and $\mathrm{Mn}$ aggregates likely explain the observed increase in totP (statistically significant only relative to the post-treatment conditions, Table 3). Verta et al. (2010) concluded that the new exposed epilimnetic sediments caused by a lowering of the thermocline were a major sink for methyl mercury in the epilimnion, which was then recorded as decreased methyl-
$\mathrm{Hg}$ concentrations in fish (Rask et al., 2010). According to Rask et al. (2010), the isotope data for Halsjärvi indicated a drop in perch $\delta^{13} \mathrm{C}$. A plausible explanation is that it reflected increased incorporation of methane-derived carbon into perch tissue in the lake, due to changes in food web structure. Change in the oxygen regime is thus a key process in small humic lakes with steep thermal and chemical stratification, and if the oxygen deficiency in the hypolimnion will be affected, the consequences for the entire ecosystem can thus be highly significant. It is likely that these oxygenrelated changes would be more important for many processes than direct temperature changes caused by climate change in these lake ecosystems.

Other key changes observed in Halsjärvi were the statistically significant decline particularly in totN, $\mathrm{NH}_{4}$ and organic carbon (both TOC and colour; Table 3, Fig. 8). For $\mathrm{NO}_{3}$ the observed decrease was not statistically significant (Table 3). The late month of June during the pre-treatment period in 2004 was exceptionally rainy (more than $80 \mathrm{~mm}$ during four days of heavy rain), causing extremely high discharge and unusually high levels of TOC in both Halsjärvi and Valkea-Kotinen (Fig. 8d). During the treatment years 2005-2006 the precipitation was close to the long-term average, which explains the reduced levels of nutrients and organic carbon during this period (treat-pre in Table 3). A straightforward explanation for some of these observed changes is that the catchment area of Halsjärvi is almost two times larger than in Valkea-Kotinen (Table 1), and therefore water residence time is shorter. Consequently the catchment area has a stronger impact on the lake, and changes in 

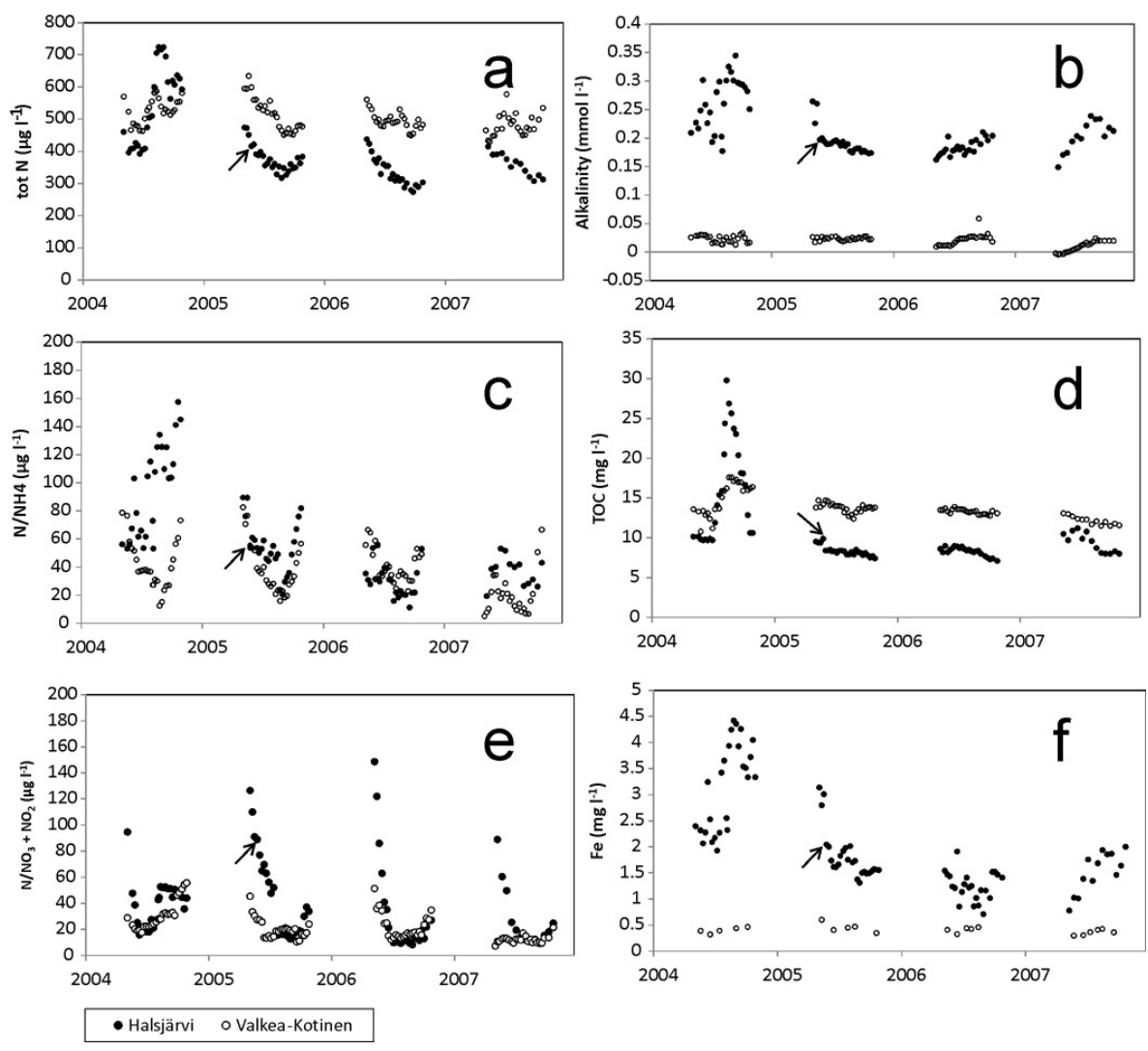

Fig. 8. Volume-weighted whole-lake concentrations of (a) totN, (b) alkalinity, (c) N/NH4, (d) TOC, (e) $\mathrm{N} / \mathrm{NO}_{3}$ and (f) Fe in lakes Halsjärvi (experimental lake) and Valkea-Kotinen (reference lake). The artificial mixing was conducted in Halsjärvi in $2005-2006$ (reference years 2004, 2007). The arrow indicates the first sample taken after the start of the manipulation experiment in 2005.

chemistry were faster and larger in Halsjärvi than in ValkeaKotinen during the high-discharge period. It is well-known that element leaching is following the precipitation pattern, with higher fluxes during periods of elevated runoff (e.g. Dillon and Molot, 1997; Correl et al., 2001).

However, the absolute differences in Halsjärvi as well as the relative difference between the lakes (Hals-Valk, Table 3 and Fig. 8) indicated that also the manipulation caused some of the observed changes. Factors which likely were affected by the artificial mixing in Halsjärvi include microbial decomposition, sedimentation and photo-oxidation of organic matter. The sedimentation traps installed in Halsjärvi indicated an increase in the gross sedimentation of dry matter by a factor of four (from $12.7 \mathrm{~g} \mathrm{~m}^{-2}$ and $11.3 \mathrm{~g} \mathrm{~m}^{-2}$ in 2004 and 2007 to $55.7 \mathrm{~g} \mathrm{~m}^{-2}$ in 2005, Verta et al., 2010). Vähätalo (2000) estimated that microbial decomposition was responsible for $93 \%$ of the organic carbon mineralization in Valkea-Kotinen during the summer months and the rest could be ascribed to the direct and indirect effects of solar radiation. Recent evidence points to the significant role of freshwater ecosystems in many carbon cycling processes, such as $\mathrm{CO}_{2}$ and $\mathrm{CH}_{4}$ efflux and $\mathrm{C}$ storage in sediments (Kortelainen et al., 2006; Tranvik et al., 2009; Rantakari, 2010).
According to Kortelainen et al. (2006), small boreal lakes are very important as conduits for transferring terrestrially fixed $\mathrm{C}$ to the atmosphere, with an annual $\mathrm{CO}_{2}$ evasion of about $50 \mathrm{Tg}$. A climatic regulation of the carbon cycling processes has previously been indicated for Finnish lakes, where the highest annual $\mathrm{CO}_{2}$ emission was observed when the precipitation was highest (Rantakari and Kortelainen, 2005). Hari et al. (2008) carried out continuous $\mathrm{CO}_{2}$ flux measurements at lake Valkea-Kotinen and observed a clear increase in flux at higher wind speeds. The lake acted as a $\mathrm{CO}_{2}$ source. $\mathrm{CO}_{2}$ fluxes were not measured in Halsjärvi, but is probable that part of the observed TOC decrease during the experimental period was, in addition to the observed increased sedimentation, due to enhanced mineralization of organic matter.

Increases in DOC concentrations have been observed in surface waters over large areas in northern Europe and North America, and processes related to both climate and deposition changes have been suggested as likely causes (Tranvik et al., 2002; Vuorenmaa et al., 2006; Monteith et al., 2007). Using the dynamic model INCA-C, Futter et al. (2009) were able to simulate present day (1990-2007) increasing trends in DOC in the lake and catchment outflow of Valkea-Kotinen as functions of observed climate and modelled $\mathrm{SO}_{4}$ deposition. 
The largest increases in DOC flux were modelled between the late 1980s and 2005. Fluxes continued to increase until around 2050, but at a lower rate. Also previously, organic $\mathrm{C}$ export simulations based on climate change scenarios and neural network modelling have indicated increasing C-fluxes in both Canadian rivers (Clair et al., 1999) and Finnish headwater streams (Holmberg et al., 2006). According to Holmberg et al. (2006), the high climate change scenario gave an increase of approximately $26 \%$ also of annual totN and totP export fluxes. Episodes with high-discharge and elevated element leaching like the one experienced during the pre-treatment period in 2004 are thus likely to increase in the future. Hence, considering the potential for both increased element leaching, the previous studies indicating climatic regulation of C-mineralization processes of Finnish lakes (Rantakari and Kortelainen, 2005; Hari et al., 2008; Rantakari, 2010), as well as the results of the present manipulation experiment, it is plausible that future climate change will emphasise the role of lakes in landscape-scale carbon and nutrient cycling and lead to changes in greenhouse gas emissions from the lake surfaces.

Compared with the whole-lake manipulation experiment conducted in the deeper, oligotrophic clear-watered lake Breisjøen in southern Norway (Lydersen et al., 2008), the changes observed in the shallow dystrophic Halsjärvi were - in line with our expectations - more distinct. The manipulation in Breisjøen increased the thermocline depth from 6 to $20 \mathrm{~m}$, the mean temperature at the time of maximum heat content from 10.7 to $17.4^{\circ} \mathrm{C}$ and delayed ice-on by about 20 days (Lydersen et al., 2008). However, despite this major perturbation, only minor changes in water chemistry occurred during the experimental manipulation. Concentrations of sulphate declined $\left(-2 \mu \mathrm{eq} 1^{-1}, p<0.01\right)$, likely due to a response to reduced deposition input and possibly increased microbial activity. In the Halsjärvi experiment a slight relative increase in sulphate was observed (Table 3, treat-pre and treat-post), possibly due to reduced sulphate reduction caused by the smaller water volume of the anoxic hypolimnion. Lydersen et al. (2008) also observed decreased concentrations of TOC $\left(-7 \mu \mathrm{moll}^{-1}, p<0.01\right)$, particulate carbon $\left(-5 \mu \mathrm{moll}^{-1}, p<0.01\right)$ and nitrogen $\left(-0.5 \mu \mathrm{mol}^{-1}\right.$, $p<0.01)$, suggesting that the manipulation enhanced the sedimentation velocity of particulate organic matter. A corresponding (but larger) decrease in TOC and totN concentrations was observed also in the Halsjärvi experiment, as well as an increase in sedimentation (Sect. 3.3). In Breisjøen there was no significant change in the concentration of phosphorus, the growth-limiting nutrient for phytoplankton. This was although water transparency increased and thus the growing conditions for phytoplankton might be better than before the mixing experiment, which was reflected to phytoplankton whose species richness increased and the composition was shifted. The manipulation did not affect zooplankton biodiversity and did not affect fish populations.
According to the results from the manipulation experiment in Halsjärvi, changes in the thermal regime and oxygen saturation may thus have significant effects on the vertical distribution of several chemical constituents, organic $\mathrm{C}$ and nutrient cycling, as well as methyl-Hg production and circulation. All these are important processes in dystrophic shallow lakes. Such lakes are very common in boreal and northern regions. In Finland there are about 56000 lakes larger than $0.01 \mathrm{~km}^{2}$ and most of them are located in forested areas and have high DOC concentration (Kortelainen et al., 1989; Forsius et al., 1990). The global extent of natural lakes is twice as large as previously known (304 million lakes; 4.2 million $\mathrm{km}^{2}$ in area) and is dominated in area by millions of water bodies smaller than $1 \mathrm{~km}^{2}$ (Downing et al., 2006). Projected climate change may thus modify their physical, chemical and biological conditions in the future.

\section{Conclusions}

The MyLake model simulations for Valkea-Kotinen assuming several climate change scenarios indicated large changes in the whole-lake mean temperature and a large decrease in the probability of ice cover. The thermocline manipulation carried out in this study resulted in large changes in the thermodynamic properties of the lake Halsjärvi which rather well represented the average simulated future increase in heat content in the summer/autumn season. Although the manipulation did not give a completely realistic picture of the expected changes in physical conditions, the design allowed an assessment of the resulting complex ecosystem responses. The manipulation experiment also gives a representative scenario for changes in single extreme years or changes in the lake wind exposure due to forest fires and/or management.

The manipulation resulted in changes in the oxygen stratification during the summer seasons of the shallow dystrophic lake Halsjärvi. The expansion of the oxic water layer (volume) increased the spatial extent of sediment surface oxicanoxic interfaces, and likely affected processes such as synthesis of methyl-Hg, sedimentation of $\mathrm{Fe}$ and Mn aggregates, and fluxes of methane-derived carbon into fish. The vertical distribution of alkalinity, nitrogen species and major cations was also affected, and increased sedimentation and decomposition likely contributed to the observed statistically significant decline in organic $\mathrm{C}$ and totN. Unfortunately, unusual hydrological conditions made the assessment of the results more uncertain. The changes in thermodynamic conditions, oxygen distribution, organic $\mathrm{C}$ and nutrient levels in Halsjärvi were large enough to induce biological responses in the aquatic food web.

Comparison with the results of the similar whole-lake manipulation experiment conducted in the deeper, oligotrophic clear-watered lake Breisjøen in southern Norway indicated that shallow dystrophic lake systems with strong internal processes, are more sensitive to physical perturbation. Small 
humic lakes are very abundant ecosystems in the boreal and northern regions, being of importance also for sedimentation of elements and as conduits for transferring terrestrially fixed $\mathrm{C}$ to the atmosphere. Within this context, the present study clearly indicated that whole-lake experiments can be a powerful method for evaluating and predicting environmental change to the perturbations caused by climate and landuse changes in these ecosystems.

Acknowledgements. This work was supported by the EU-project EUROLIMPACS (GOCE386 CT-2003-505540) and the PRO-DOC project of the Academy of Finland (127922).

Edited by: A. Butturini

\section{References}

Arvola, L., Salonen, K., Kankaala, P., and Lehtovaara, A.: Vertical distributions of bacteria and algae in a deeply stratified humic lake under high grazing pressure from Daphina longispina, Hydrobiologia, 229, 253-269, 1992.

Carpenter, S. R., Frost, T. M., Heisley, D., and Kratz, T. K.: Random intervention analysis and the interpretation of whole-ecosystem experiments, Ecology, 70, 1142-1152, 1989.

Carpenter, S. R., Chrisholm, S. W., Krebs, C. J., Schindler, D. W., and Wright, R. F.: Ecosystem experiments, Science, 269, 324327, 1995.

Clair, T. A., Ehrman, J. M., and Higuchi, K.: Changes in freshwater carbon export from Canadian terrestrial basins to lakes and estuaries under a $2 \mathrm{xCO}_{2}$ atmospheric scenario, Glob. Biogeochem. Cy, 13, 1091-1097, 1999.

Correll, D. L., Jordan, T. E., and Weller, D. E.: Effects of precipitation, air temperature and land use on organic carbon discharges from Rhode river watersheds, Water, Air and Soil Pollut., 128, 139-159, 2001

Dillon, P. J. and Molot, L. A.: Dissolved organic and inorganic carbon mass balances in central Ontario lakes, Biogeochemistry, 36, 29-42, 1997.

Dokulil, M., Jagsch, A., George, G. D., Anneville, O., Jankowski, T., Wahl, B., Lenhart, B., Blenckner, T., and Teubner, K.: Twenty years of spatial coherent deepwater warming in lakes across Europe related to the North Atlantic Oscillation, Limnol. Oceanogr., 51, 2787-2793, 2006.

Downing, J. A., Prairie, Y. T., Cole, J. J., Duarte, C. M., Tranvik, L. J., Striegl, R. G., McDowell, W. H., Kortelainen, P., Caraco, N. F., Melack, J. M., and Middelburg J.: The global abundance and distribution of lakes, ponds, and impoundments, Limnol. Oceanogr., 51(5), 2388-2397, 2006.

Fee, E. J., Shearer, J. A., DeBruyn, E. R., and Schindler, E. U.: Effects of lake size on phytoplankton photosynthesis, Can. J. Fish. Aquat. Sci., 49, 2445-2459, 1992.

Fee, E. J., Hecky, R. E., Kasian, S. E. M., and Cruishank, D. R.: Effects of lake size, water clarity and climatic variability on mixing depths in Canadian shield lakes, Limnol. Oceanogr., 41(5), 912-920, 1996.

Forsius, M., Malin, V., Mäkinen, I., Mannio, J., Kämäri, J., Kortelainen, P., and Verta, M.: Finnish lake acidification survey: Survey design and random selection of lakes, Environmetrics, 1, 73-88, 1990.
Forsius, M., Johansson M., Posch, M., Holmberg, M., Kämäri, J., Lepistö, A., Roos, J., Syri, S., and Starr, M.: Modelling the effects of climate change, acidic deposition and forest harvesting on the biogeochemistry of a boreal forested catchment in Finland, Boreal Environ. Res., 2, 129-143, 1997.

Futter, M. N., Forsius, M., Holmberg, M., and Starr, M.: A longterm simulation of the effects of acidic deposition and climate change on surface water dissolved organic carbon concentrations in a boreal catchment, Hydrol. Res., 40, 291-305, 2009.

Hari, P., Pumpanen, J., Huotari, J., Kolari, P., Grace, J., Vesala, T., and Ojala, A.: High-frequency measurements of productivity of planktonic algae using rugged nondispersive infrared carbon dioxide probes, Limnol. Oceanogr. Methods 6, 347-354, 2008.

Holmberg, M., Forsius, M., Starr, M., and Huttunen, M.: An application of artificial neural networks to carbon, nitrogen and phosphorus concentrations in three boreal streams and impacts of climate change, Ecol. Model., 195, 51-60, 2006.

Järvinen, M., Rask, M., Ruuhijärvi, J., and Arvola, L.: Temporal coherence in water temperature and chemistry under the ice of boreal lakes (Finland), Water Res., 36, 3949-3956, 2002.

Jones, R. I. and Arvola, L.: Light penetration and some related characteristics in small forest lakes in Southern Finland, Verh. Int. Verein. Limnol., 22, 811-816, 1984.

Jones, C. G., Willén, U., Ullerstig, A., and Hansson, U.: The Rossby Centre Regional Atmospheric Climate Model Part I: Model Climatology and Performance for the Present Climate over Europe, Ambio, 33, 199-210, 2004.

Jylhä, K., Tuomenvirta, H., and Ruosteenoja, K.: Climate change projections for Finland during the 21st century, Boreal Env. Res., 9, 127-152, 2004.

Keskitalo, J., Salonen, K., and Holopainen, A.-L.: Long-term fluctuations in environmental conditions, plankton and macrophytes in a humic lake, Valkea-Kotinen, Bor. Environ. Res., 3, 251-262, 1998.

Korhonen, J.: Long-term changes in lake ice cover in Finland, Nordic Hydrology, 37, 347-363, 2006.

Koroleff, F.: Methods for the chemical analysis of seawater, Meri, Vol. 7, Institute of Marine Research, Helsinki, 1-60, 1979 (in Finnish).

Kortelainen, P., Mannio, J., Forsius, M., Kämäri, J., and Verta, M.: Finnish lake survey: the role of organic and anthropogenic acidity, Water Air Soil Pollut., 46, 235-249, 1989.

Kortelainen, P., Rantakari, M., Huttunen, J. T., Mattsson, T., Alm, J., Juutinen, S., Larmola, T., Silvola, J., and Martikainen, P. J.: Sediment respiration and lake trophic state are important predictors of large $\mathrm{CO}_{2}$ evasion from small boreal lakes, Global Change Biology, 12, 1554-1567, 2006.

Livingstone, D. M. and Dokulil, M. T.: Eighty years of spatially coherent Austrian lake surface temperatures and their relationship to regional air temperature and the North Atlantic Oscillation, Limnol. Oceanogr., 46, 1220-1227, 2001.

Livingstone, D. M., Lotter, A. F., and Kettle, H.: Altitudedependent differences in the primary physical response of mountain lakes to climatic forcing. Limnol. Oceanogr., 50(4), 13131325, 2005.

Lydersen, E., Aanes, K. J., Andersen, S., Andersen, T., Brettum, P., Baekken, T., Lien, L., Lindstrøm, E. A., Løvik, J. E., Mjelde, M., Oredalen, T. J., Solheim, A. L., Romstad, R., and Wright, R. F.: Ecosystem effects of thermal manipulation of a whole lake, Lake 
Breisjøen, southern Norway (THERMOS project), Hydrol. Earth Syst. Sci., 12, 509-522, doi:10.5194/hess-12-509-2008, 2008.

Monteith, D. T., Stoddard, J. L., Evans, C. D., de Wit, H. A., Forsius, M., Høgåsen, T., Wilander, A., Skjelkvåle, B. L., Jeffries, D. S., Vuorenmaa, J., Keller, B., Kopácek, J., and Vesely, J.: Dissolved organic carbon trends resulting from changes in atmospheric deposition chemistry, Nature, 450, 537-540, 2007.

Nickus, U., Bishop, K., Erlandsson, M., Evans, C. D., Forsius, M., Laudon, H., Livingstone, D. M., Monteith, D., and Thies, H.: Direct impacts of climate change on freshwater ecosystems, in: Climate Change Impacts on Freshwater Ecosystems, edited by: Kernan, M., Battarbee, R. W., and Moss, B., Hoboken, NJ, Wiley-Blackwell, 38-64, 2010.

Peeters, F., Straile, D., Lorke, A., and Livingstone, D. M.: Earlier onset of spring phytoplankton growth in lakes of the temperate zone in a warmer climate, Global Change Biol., 13(9), 18981909, 2007.

Rantakari, M.: The role of lakes in carbon cycling in boreal catchments, Monographs of the Boreal Environment Research, 35, 32 pp., 2010.

Rantakari, M. and Kortelainen, P.: Interannual variation and climatic regulation of the $\mathrm{CO}_{2}$ emission from large boreal lakes, Global Change Biol., 11, 1368-1380, 2005.

Räisänen, J., Hansson, U., Ullerstig, A., Döscher, R., Graham, L. P., Jones, C., Meier, H. E. M., Samuelsson, P., and Willén, U.: European climate in the late twenty-first century: regional simulations with two driving global models and two forcing scenarios, Clim. Dyn., 22, 13-31, 2004.

Rask, M., Verta, M., Korhonen, M., Salo, S., Forsius, M., Arvola, L., Jones, R. I., and Kiljunen, M.: Does lake thermocline depth affect methyl mercury concentrations in fish?, Biogeochemistry, 101, 311-322, 2010.

Saloranta, T. M. and Andersen, T.: MyLake - A multi-year lake simulation model suitable for uncertainty and sensitivity analysis simulations, Ecol. Model., 207, 45-60, 2007.

Saloranta, T. M., Forsius, M., Järvinen, M., and Arvola, L.: Impacts of projected climate change on thermodynamics of a shallow and deep lake in Finland: Model simulations and Bayesian uncertainty analysis, Hydrol. Res., 40, 234-248, 2009.

Schindler, D. W., Bayley, S. E., Parker, B. R., Beaty, K. G., Cruickshank, D. R., Fee, E. J., Schindler, E. U., and Stainton, M. P.: The effects of climatic warming on the properties of boreal lakes and streams at the experimental lakes area, Northwestern Ontario, Limnol. Oceanogr., 41, 1004-1017, 1996a.

Schindler, D. W., Curtis, P. J., Parker, B. R., and Stainton, M. P.: Consequences of climate warming and lake acidification for UVB penetration in North American boreal lakes, Nature, 379, 705708, 1996b.

Snucins, E. and Gunn, J.: Interannual variation in the thermal structure of clear and colored lakes. Limnol. Oceanogr., 45(7), 16391648, 2000.
Solorzano, L.: Determination of ammonia in natural waters by the phenolhypochlorite method, Limnol. Oceanogr., 14, 799-801, 1969.

Starr, M., and Ukonmaanaho, L.: Results from the first round of the integrated monitoring soil chemistry subprogramme, in: Forest Condition in Finland. edited by: Ukonmaanaho, L. and Raitio, H., National Report 2000, Finnish Forest Research Institute, Helsinki, Research Papers 824, 140-157, 2001.

Steedman, R. J. and Kushneriuk, R. S.: Effects of experimental clearcut logging on thermal stratification, dissolved oxygen and lake trout (Salvelinus namaycush) habitat volume in three small boreal lakes, Can. J. Fish. Aquat. Sci. 57 Suppl. 2, 82-91, 2000.

Tranvik L. J. and Jansson M.: Climate change - terrestrial export of organic carbon, Nature, 415, 861-862, 2002.

Tranvik, L. J., Downing, J. A., Cotner, J. B., Loiselle, S. A., Striegl, R. G., Ballatore, T. J., Dillon, P., Finlay, K., Fortino, K., Knoll, L. B., Kortelainen, P., Kutser, T., Larsen, S., Laurion, I., Leech, D. M., Leigh Mccallister, S., McKnight, D. M., Melack, J. M., Overholt, E., Porter, J. A., Prarie, Y., Renwick, W. H., Roland, F., Sherman, B. S., Schindler, D. W., Sobek, S., Tremblay, A., Vanni, M. J., Vershoor, A. M., von Wachenfeldt, E., and Weyhenmeyer, G. A. : Lakes and reservoirs as regulators of carbon cycling and climate, Limnol. Oceanogr., 54(6, part 2), 2009, 22982314, 2009.

Vähätalo, A. V.: Role of photochemical reactions in the biogeochemical cycling of detrital carbon in aquatic ecosystems, Academic Dissertation in Microbiology, University of Helsinki, Finland, 2000.

Verta, M., Salo, S. Porvari, P., Korhonen, M., Paloheimo, A., and Munthe, J.: Climate induced thermocline change has an effect on the methyl mercury cycle in small boreal lakes, Sci. Total Environ., 408(17), 3639-3647, 2010.

Vuorenmaa, J., Forsius, M., and Mannio, J.: Increasing trends of total organic carbon concentrations in small forest lakes in Finland from 1987 to 2003. Sci. Total Environ., 365, 47-65, 2006.

Weyhenmayer, G. A., Westö, A-K., and Willen, E.: Increasingly ice-free winters and their effects on water quality in Sweden's largest lakes, Hydrobiologia, 599, 111-118, 2008.

Wood, E. D., Armstrong, F. A. J., and Richards, F. A.: Determination of nitrate in sea water by cadmium copper reduction to nitrite, J. Mar. Biol. Assoc. UK, 47, 23-31, 1967.

Wright, R. F.: Effects of increased carbon dioxide and temperature on runoff chemistry at a forested catchment in Southern Norway (CLIMEX project). Ecosystems, 1, 216-225, 1998.

Xenopoulus, M. A. and Schindler, D. W.: The environmental control of near-surface thermoclines in boreal lakes, Ecosystems 4, 699-707, 2001. 